J. Perinat. Med. 6 (1977) 268

\section{Utero-placental blood flow index. Its relationship with the placental histology and fetal hypoxia}

\author{
José A. Clavero-Núñez and Luis Ortiz-Quintana
}

Department of Obstetrics and Gynaecology at the Complutense University, Cuidad Sanitaria Provincial Francisco Franco. Madrid.

\section{Introduction}

Attempts are being made to introduce the use of radioactive tracers into obstetrical practice to study uteroplacental blood flow as a means of assessing placental function and, indirectly, fetal well-being. Of the various techniques that have been employed the most useful fall into two groups. First, there are those techniques which measure the clearance of a radioisotope injected into the intervillous space, as originally suggested by BROWN and his colleagues [3,9] using ${ }^{24} \mathrm{Na}$. Later GuILHEIM et al. [11] and Clavero et al. [5, 6, 7] using ${ }^{133} \mathrm{Xe}$ obtained better results. However puncturing the intervillous space has several drawbacks as indicated for instance by LIPPERT et al. [15]. To avoid them several ingenious techniques have been proposed in which the ${ }^{133} \mathrm{Xe}$ reaches the intervillous space indirectly, either by maternal inhalation $[12,25]$ or by injection into a branchial vein [19]; the measurement of clearance of the labelled gas from the intervillous space is the basis of these techniques. The second group comprises those techniques that determine the arrival and distribution of a radioisotope in the intervillous space after injection into a brachial vein. The isotopes used have been ${ }^{125}$ I [20], ${ }^{99} \mathrm{Tc}[14]$ and especially ${ }^{113 \mathrm{~m}}$ In $[1,8,10$, $13,18,22]$. Detection of radioactivity has been with a multiprover or with gammacamera. JANISCH et al. [14] who have used both ${ }^{113 \mathrm{~m}} \mathrm{In}$ and ${ }^{99} \mathrm{Tc}$ consider using ${ }^{113 \mathrm{~m}}$ In with the gammacamera to be best. This has the advantage of covering almost

\section{Curriculum vitae}

Dr.CLAVERO-NUNEZ was born in 1935 in Valencia (Spain). He obtained his medical degree at Madrid University in 1961, specialized in Obstetrics and Gynecology and became Assistant to Professor BOTELLA-LLUSIA in the Complutense University of Madrid in 1967. Two years later he was appointed Professor at the Complutense University of Madrid in 1967. Two years later he was appointed Professor and Chairman at Salamanca, and in 1972-Professor at the Complutense University of Madrid (Dept. of Obstetrics and Gynecology at Ciudad Sanitaria Provincial Francisco Franco). He has been interested in perinatal research since 1960 , especially concerning the human placenta.

the whole uterus with the placental zone. The detection system must be combined with a scanning system which can record the isotope arrival curve. Different parameters of this curve have been used to calculate the uteroplacental blood flow. Thus there exists a great variety of techniques which are not readily comparable.

In this paper we describe our findings using a gammacamera to determine ${ }^{113 \mathrm{~m}}$ In in the uteroplacental compartment. 


\section{Material and method}

We injected ${ }^{113 \mathrm{~m}}$ In-gelatin into a cubital vein, in a dose of $15 \mu \mathrm{ci} / \mathrm{Kg}$. The patient was standing, her abdomen resting on the detector of a Pho-Gamma III gammacamera. Previously the placenta was located by echography, then the detector was situated to face the whole placental zone and a large part of the myometrium. The patient rested her abdomen and arms on the detector so that perceptible movements during the observation were avoided. The exploration time was $\bar{X}=2.15$ min. \pm 0.18 minutes. The detector was connected to a monitoring system so as to observe the arrival of the radioisotope in the uteroplacental com- partment. The curve recorded was analyzed only in the section from the beginning of the rise to the point of appreciable stabilization. Some records showed marked oscillations, probably due to uterine activity. Since it was difficult in these cases to establish the point of stabilization, they were discarded. To give the analysis of the above mentioned section of the curve the formula $F / V$ $=0.693 / \mathrm{T}_{1 / 2} \times 100$ was applied. The result called „uteroplacental blood flow index" is expressed in \%.

By this method we studied 114 patients, of whom 57 were selected (with or without fetal risk) according to the following criteria: (1) Gestation lasted 37 weeks or more (2). In cases with possible

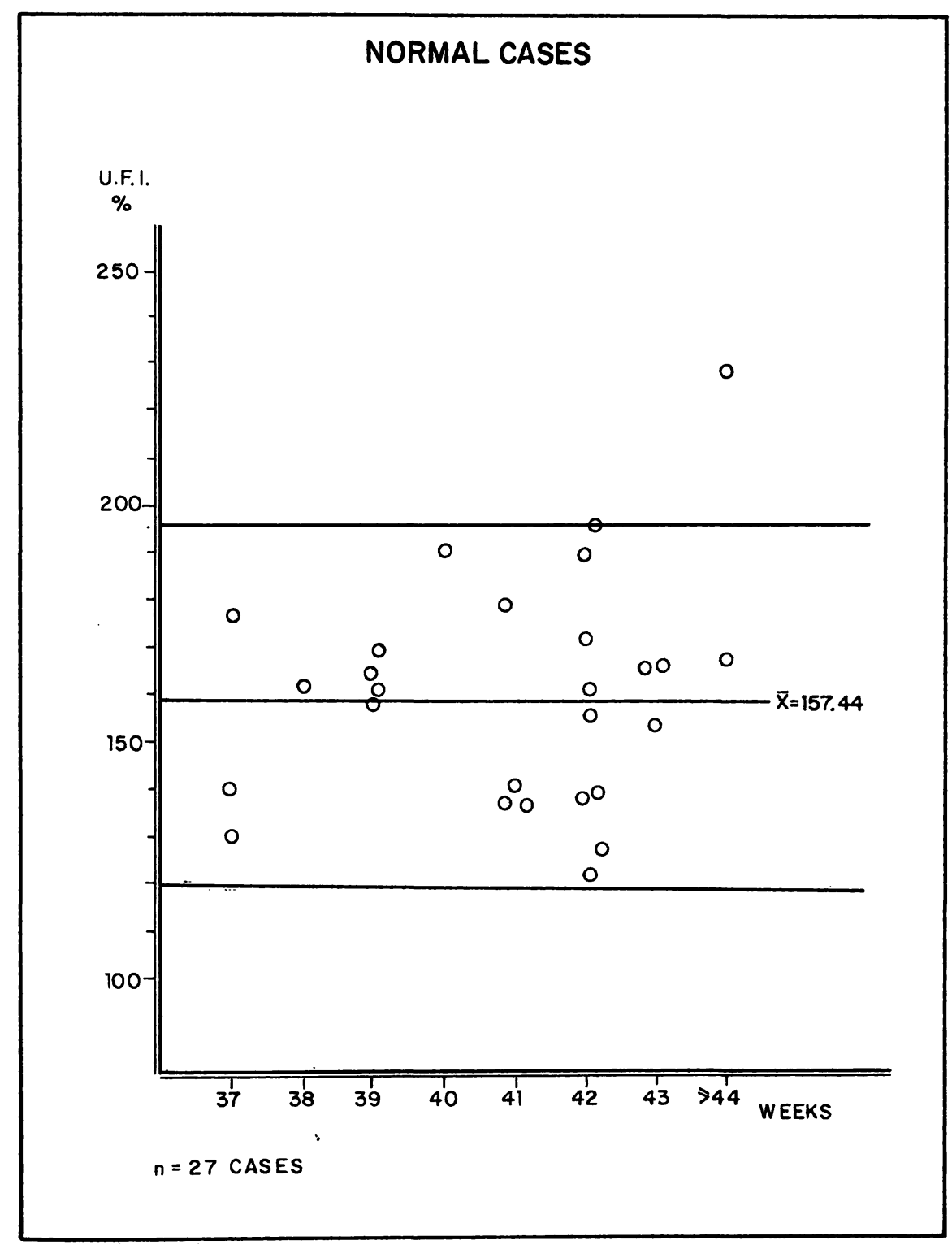

Fig. 1. Uteroplacental blood flow index in 27 cases with normal placenta and without fetal hypoxia. The mean was $157.44 \pm 18.39 \%$. The $95 \%$ confidence limits are values of $195 \%$ and $120 \%$. 
fetal risk fetal wellbeing was assured by various tests including amnioscopy, echography and the oxytocin challenge test, but the uteroplacental blood flow index was not taken into account (3). The delivery took place within a week after the study has been carried out (4). Labor was monitored by recording FHR and uterine activity, and only cases with normal uterine action were included (5). Delivery was not traumatic for the fetus, or when effected surgically (cesarean section, low forceps, vacuum extractor) was easy and the neonatologist did not find any fetal damage attributable to it (6). There was no cord prolapse or knot (7). The newborn was considered as at term.

In this way we attempted to eliminate prematurity, anomalies of the cord, obstetrical trauma and incoordinate uterine activity as causes of intrapartum fetal distress or of a depressed neonate. Finally, the placenta was' studied histologically and classified as mature, postmature or senescent, according to criteria similar to those of WILKIN [24].

\section{Results}

Our material was classified according to the histology of the placenta. In 27 cases it was normal (mature) and in this group we found no intrapartum fetal distress and the neonate was vigorous. In 30 cases the placenta was pathological (postmature or senescent) and in 17 of these cases

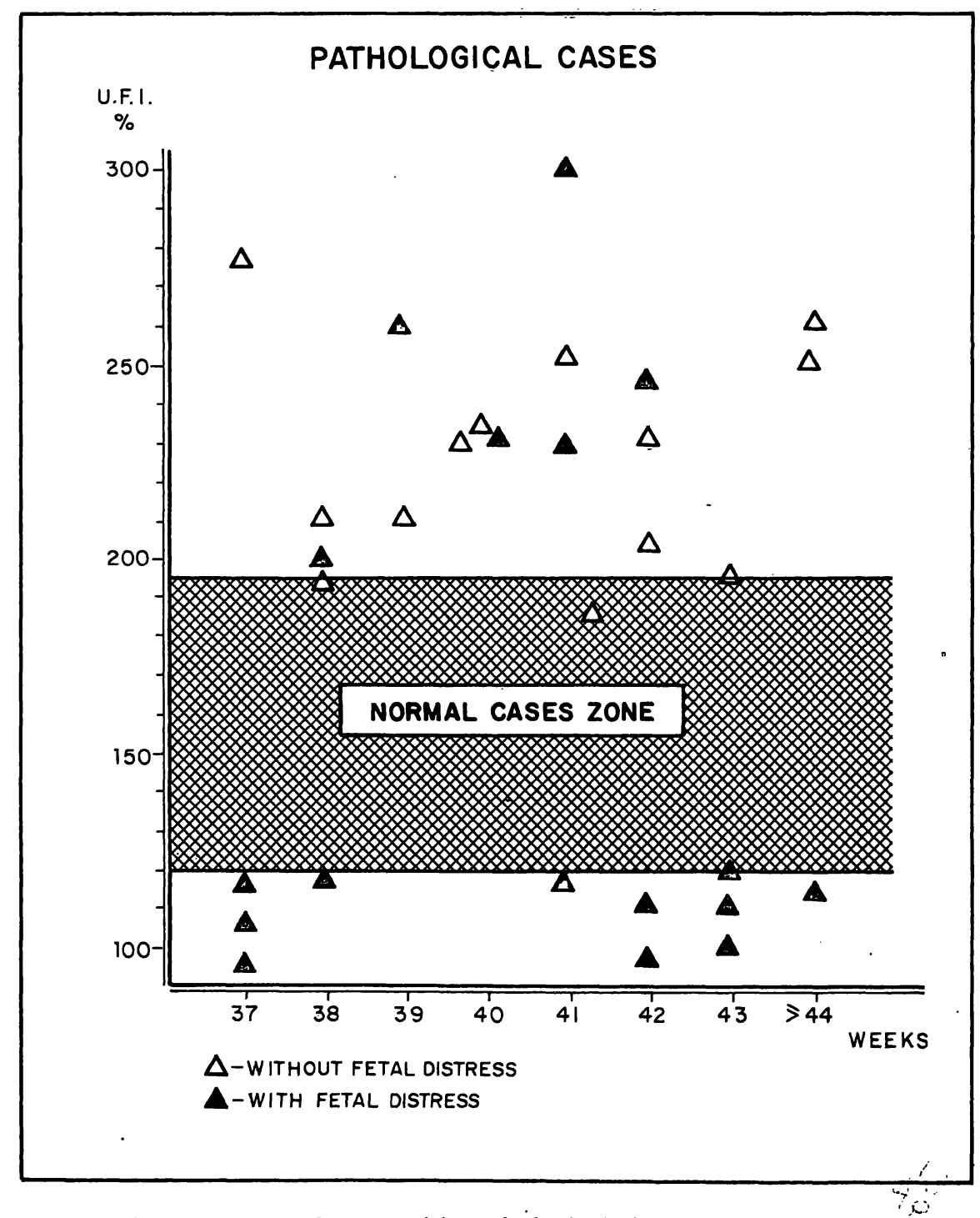

Fig. 2. Uteroplacental blood flow index in 30 cases with pathological placenta and excluding all but placental causes of fetal hypoxia. Note that nearly all the cases are situated outside the ,normal cases zone“. When the index is below $120 \%$ hypoxia appears in all the cases studied. 
intrapartum fetal distress was observed, 16 babies were born depressed and 3 died.

The values of the uteroplacental blood flow index in the normal group are shown in Fig. 1. The mean was $\bar{X}=157.44 \pm 18,39 \%$. The $95 \%$ confident limits (from $120 \%$ to $195 \%$ ) are used to define the "normal cases zone".

Fig. 2 shows the values found in cases with abnormal placentas and it is noteworthy that they nearly all fall outside the ,normal cases zone“. In 19 cases values were above or very near the upper limits, and within this group were 6 with fetal distress during labor, of which 5 had neonatal depression although they all recovered within 5 minutes (Apgar score $>7$ ). Values below the „normal case zone“ occured in 11 cases and all were associated with fetal distress during labor and neonatal depression. Six of the neonates remained depressed for five minutes and three died. The diagnosis of the neonatologist and from necropsy findings was hypoxia.

\section{Comments}

$113 \mathrm{~m}$ In-gelatin is an iodinated radioisotope for use during pregnancy. Its application to localize the placenta is well known, and we have used it for this purpose [17]. Its advantages include a short half life of 100 minutes, emission of gammaradiation of $393 \mathrm{Kev}$, and binding with plasma proteins which prevents loss from the vascular system to any appreciable extent [21]. Also it does not diffuse into the amniotic fluid [2]. With a dose of 1 mci injected, the mother receives a body dose of $176 \mathrm{mrad}$, while the blood dose is $146 \mathrm{mrad}$ [23]. The calculated dose received by the fetus is $5-8 \operatorname{mrad}[16,23]$.

If ${ }^{113 \mathrm{~m}}$ In-gleatin is an iodinated radioisotope, the gammacamera seems to give better information

\section{Summary}

This paper describes the method used to estimate an index of uteroplacental blood flow in 114 patients examined standing and with a pregnancy of 37 weeks of more. The findings are described in 57 cases (with or without fetal risk), which were selected by placental function tests as being suitable for vaginal delivery. Here, the uteroplacental blood flow index was not taken into account. After delivery possible obstetrical causes of fetal damage were about its arrival in the uteroplacental compartment than the multiprover. JANISCH et al. [14] agree on those points.

With regard to the position of the patient, we believe that the supine position (as is described by all other authors) is not the most suitable. We think it is possible that positional changes affect uteroplacental blood flow as happens with renal flow [4]. In that case, findings in the supine position may not accurately reflect the usual situation in pregnancy.

The results we have obtained should not be compared with those of other authors, in so far as there are notable differences in the method and in the analysis of the curves, and in the selection of material. Thus, for example, although both JANISCH et al. [13, 14] and GROB et al. [10] used $113 \mathrm{~m}$ In and the gammacamera, the former expressed their results in $\mathrm{ml} / 100 \mathrm{gr} / \mathrm{min}$ and the latter in an index different from ours. The patients of both were examined in decubitus and their ,normal cases" form a group very different from ours. Ours are based on histological study of the placenta, and do not include any premature fetus, incoordinate uterine activity, traumatic delivery or cord accident. Perhaps due to this selection our cases of fetal distress during labor and neonatal depression can be attributed confidently to abnormal placental function. This may explain why in our material there was not a single case of a normal placenta with fetal damage.

Finally, we emphasize that our method seems to allow assessment of the degree of maturity of the placenta and, indirectly, the state of the fetus. It has not been compared with other techniques used for this aim because we consider it as complementary to them. Our results suggest it could be usefully adopted as an obstetric criterion in those cases where there is fetal risk.

excluded, leaving only cases due to placental causes. All placentas were studied histologically.

The 27 cases with normal placenta had an index of $\bar{X}=157.44 \pm 18,39 \%$ (95\% confidence limits $120 \%$ and $195 \%)$. There were no cases of fetal damage in this group.

The 30 cases with pathological placenta had an index above or below the normal limits. In 19 cases with high 
values there were 6 with fetal distress during labor, including 5 with neonatal hypoxia but recoverin within 5 minutes. The 11 cases with low values had fetal distress during labor and neonatal depression. Six neonates continued in this state after 5 minutes and 3 died from hypoxia.
The indexobtained seems to indicate the degree of placental normality and to be of use in determining the obstetrical procedure in cases with fetal risk.

Keywords: Fetal risk, indium $113 \mathrm{~m}$, placental function, placental histology, uteroplacental blood flow.

\section{Zusammenfassung}

Der uteroplacentare Durchströmungsindex und seine Beziehungen zur Placentahistologie und zur fetalen Hypoxie.

Diese Arbeit beschreibt die Bestimmung der uteroplacentaren Durchblutungsgrößen bei 114 im Stehen untersuchten Patientinnen mit Schwangerschaften von 37 oder mehr Wochen. Es wurden 57 Patientinnen (mit oder ohne fetales Risiko) ausgewählt, bei denen der Test durchgeführt wurde mit dem Ziel, die o. g. Risiken abzuklären; die Patientinnen durften vaginal entbinden, wobei die Ergebnisse unserer Index-Bestimmung allerdings nicht berücksichtigt wurden. Nach erfolgter Geburt wurden alle Ursachen für eine fetale Schädigung mit Ausnahme der placentaren Ursachen ausgeschlossen. Alle Placenten sind histologisch untersucht worden.

Die 27 Fälle mit normaler Placenta haben einen mittleren Index von $\bar{X}=157.44 \pm 18,39 \%$ (95\%ige Vertrauensgren- zen bei diesen Fällen 120 bis 195\%). Dabei war kein Fall mit fetaler Schädigung.

Bei den 30 Fällen mit pathologischer Placentahistologie fand sich ein Index, der höher oder niedriger war als die zuvor erwähnten Vertrauengrenzen.

Unter den 19 angesprochenen Fällen waren 6 mit fetal distress während der Geburt, 5 dieser Feten wurden hypoxisch geboren, erholten sich jedoch innerhalb von 5 Min. Die restlichen 11 Fälle mit niedrigen Indices zeigten ebenfalls fetal distress während der Geburt und wurden auch in deprimiertem Zustand geboren. 6 Kinder waren nach 5 Minuten weiterhin deprimiert und 3 dieser Gruppe starben infolge der Hypoxie. Der errechnete Index scheint den Umfang der placentaren Integrität widerzuspiegeln und kann bei der Geburtsleitung von Risikofällen von Nutzen sein.

Schlüsselwörter: Fetales Risiko, Indium $113 \mathrm{~m}$, Placentafunktion, Placentahiștologie, uteroplacentare Durchblutung.

\section{Résumé}

Index du débit sanguin utero-placentaire et sa relation avec l'histologie placentaire et l'hypoxie foetale

Le présent article analyse la méthode de calcul du débit sanguin utéroplacentaire chez 114 parturientes examinées en permanence à un stage de grossesse atteignant au moins la 37 ème semaine. 57 ont été sélectionnées (avec ou sans risque foetal) chez lesquelles le test effectué pour évaluer le risque mentionné ci-dessus a autorisé l'accouchement vaginal mais sans empiéter sur le résultat de notre index. Après l'accouchement on a pu écarter les causes possibles de lésion foetale, à l'exception des causes placentaires. Tous les placentaires ont été soumis à un examen histologique.

Les 27 cas de placentaire normal ont montré un index de
$\bar{X}=157.44 \pm 18,39 \%$ (limites de garantie de $95 \%$ des cas: $120 \%$ et $195 \%$ ). On n'a relevé aucun cas de lésion foetale.

Les 30 cas de placentaire pathologique ont révélé un index plusélevé ou plus bas que les limites de garantie mentionnées ci-dessus. Dans 19 cas à l'index plus élevé, on a noté 6 cas de distress foetal en cours de travail, 5 de ces foetus étant nés avec une hypoxie foetale, mais ayant récupéré en moins de 5 minutes. Les 11 cas à l'index situé plus bas ont montré un distress foetal durant le travail et sont nés «depressed». Six sont restés dans cet état après 5 minutes et 3 d'entre eux sont morts d'hypoxie.

L'index obtenu semble indiquer le degré de normalité placentaire et semble être utile pour déterminer la méthode obstétrique dans les cas de risque foetal.

Mots-clés: Débit sanguin utéroplacentaire, fonction placentaire, histologie placentaire, indium $113 \mathrm{~m}$, risque foetal.

Bibliography

[1] ANTAR, M. A., R. P. SPENCER: Dynamics of placental and uterine blood flow. A functional index using $(113 \mathrm{~m})$. Obstet. and Gynec. 40 (1972) 385 $\because$

[2] BIGGS, J. S. G., I. H. BUTIFIELD: Radioactive Indium is not readly transferred to the amniotic fluid Aust. N. Z. J. Gynaec. 13 (1973) 163 
[3] BROWN, J. C. MCCLURE, N. VEAL: The maternal placental blood flow in normotensive and hypertensive women. J. Obstet. Gynaec. Brit. Emp., 60 (1953) 141

[4] CHESLEY, L. C., D. M. SlOAN: Effect of posture on renal function in late pregnancy. Amer. J. Obstet. Gynec., 89 (1964) 754

[5] CLAVERO-NUNEZ, J. A., J. NEGUERUELA, J. ESTEBAN, J. ALVAREZ, J. AUSIN, A. RETAMAR: El intercambio gaseoso en el feto durante el embarazo. Estudio experimental con 133Xe. Acta Gin. 19 (1968) 675

[6] CLAVERO-NUÑEZ, J. A., J. NEGUERUELA, L. QUINTANA, J.ALVAREZ,S.PEREZ-MODREGO: Blood flow in the intervillous space and fetal blood flow. (I): Normal values in human pregnancies at term. Amer. J. Obstet. Gynec., 116 (1973) 340

[7] CLAVERO-NUÑEZ, J. A., L. ORTIZ-QUINTANA, J. ALVAREZ, J. NEGUERUELA: Blood flow in intervillous space and fetal blood flow. (II): Relation to placental histology and histometry in cases with and without fetal risk. Amer. J. Obstet. Gynec., 116 (1973) 1157

[8] CLAVERO-NUÑEZ, J. A., L. ORTIZ-QUiNTANA: A clinical study on the uteroplacental blood flow at term. 5 th European Congress of Perinatal Medicine. Abstract no. 47. Uppsala, 9-12 June 1976. Almqvist \& Wiksell Inter. Stockholm 1976.

[9] DIXON, H. G., J. C. MCCLURE BROWN, D. A. DAVEY: Choriodecidual and myometrial blood flow. Amer. J. Obstet. Gynec., 90 (1964) 277.

[10] GROB, J. C., J. C. SCHUMACHER, R. WALCH, G. METHLIN, J. RITTER, J. GANDAR: Estimation of the placental blood flow with the index of placental circulation (I.P.C.). Its use to discriminate two categories of small for dates infants. 5 th European Congress of Perinatal Medicine. Abstract no. 48. Uppsala 9-12 June 1976. Almqvist \& Wiksell Inter. Stockholm 1976

[11] GUILHEM, P., A.PONTONNIER, G.PONTONNIER: Mesure du débit uterin par le Xenon $133 \mathrm{chez}$ la femme enceinte. Gynec. Obstet. 64 (1965) 313

[12] JACOBY, H. E., R. N. ARNOT, H. L. GLASS, J. C. M. BROWN: Estimation of clearance rate of inhaled Xenen-133 in the placental region of the pregnant uterus. J. Obstet. Gynaec. Brit. Cwlth. 79 (1972) 531
[13] JANISCH, H., S. LEODOLTER: Plazentainsuffizienz und Funktionsdiagnostik mit Radioisotopen. Z. Geburtsh. Perinat. 177 (1973) 11

[14] JANISCH, H., S. LEODOLTER, J. SPONA: Die Plazentainsuffienz. Neue diagnostische Methoden zur Erfassung der Risikoschwangerschaft. Wien. Klin. Wschr. 85 (1973) 3

[15] LIPPERT, T. H., R. FRIEDRICH, P. HINDEMANN: Critical assesment of the Xenon washout technic for measurement of placental blood flow. Gynec. Invest. 4 (1973) 14

[16] LIPPERT, T. H., S. E. CLOEREN, R. FRIEDRICH, M. HINSELMANN: Continous recording of uteroplacental blood volume in the human. Acta Obstet. Gynec. Scand. 52 (1973) 131

[17] ORTIZ-QUINTANA, L., J. A. CLAVERO-NUÑEZ: Diagnostico de la localización placentaria mediante gammagrafia. Revisión del problema. Acta Gin. 25 (1974) 771

[18] RENAUD, R., A. BOCK, R. BIDET, M. STEINLING, H. GRAF, J. CHAMBRON: Etude simultanée des circulations placentaire, myométriale et cervicale (In 113 et thermométrie anémometrique) I. Technique. J. Gynec. Obstet. Biol. Reprod. 3 (1974) 1267

[19] REKONEN, A., H. LUOTOLA, M. PITKANEN, J. RUIKKA, T. PYORALA: Measurement of intervillous and myometrial blood flow by an intravenous 133 Xe method. J. Obstet. Gynaec. Brit. Cwlth 83 (1976) 723

[20] SMITH, R. W.: Cardovascular alterations in toxemia. Amer. J. Obstet. Gynec., 107 (1970) 979.

[21] STERN, H. S., D. A. GOODWIN, U. SCHEFFEL, H. N. WAGNER, H. H. KRAMER: In $113 \mathrm{~m}$ for blood-pool and brain scanning. Nucleonics 25 (1967) 62

[22] STOLP, W., B. HUNERMANN, S. MUND-HOYM, M. HANSMANN: Zur Überwachung der Risikoschwangerschaft. Fortschr. Med. 92 (1974) 427

[23] VAN DER MERWE, E. J., M. J. LOTTER, P. D. R. VAN HEERDEN: Absorved dose calculations for $113 \mathrm{~m}$ In placental scanning. J. Nucl. Med. 11 (1970) 31

[24] WILKIN, P.: Pathologie du Placenta. Etude clinique et anatomique. Masson et Cie. Paris 1965

[25] WOLFSON, M.R., K. C. H. BLAKE: Isotopic Methods using Xenon 133 for assessing placental blood flow and for detecting late-for-dates babies. S. Afr. Med. J. 49 (1975) 117

Received June 13, 1976. Accepted March 15, 1977.

Prof. Dr. med. J. A. Clavero-Núñez

Catedratico de Obstetricia y Ginecologia Avda. Generalissimo no. 12

Madrid 16

SPAIN 